\title{
Compliance With Sarbanes-Oxley Requires Formal Ethics Training: Are You Doing It?
}

Donna Galla, (E-mail: Galla@nova.edu), Nova Southeastern University

Frank Cavico, (E-mail: Cavico@nova.edu), Nova Southeastern University

Bahaudin Mujtaba, (E-mail: Mujtaba@sbe.nova.edu), Nova Southeastern University

\begin{abstract}
This paper focuses on the business environment post Sarbanes-Oxley Act of 2002 (SOX). The premise of this paper is that after decades of an eroding of regulations to prevent corporate and personal self-serving behavior, the legislation of the Sarbanes-Oxley Act of 2002 (SOX) is not enough to prevent unethical behavior. Kohlberg's moral development theory states that cognitive ethical reasoning becomes more complex as one matures and gains cognitive processes. This theory assumes anyone with lower-order ethical reasoning is not able to process higher-order ethical reasoning. The theory is another indication that high ethical standards exhibited today do not guarantee the same standards tomorrow. Ethics theories and Rest's four-component model is briefly discussed. This paper concludes with an ethical business training model which can serve as a guideline for accessing and improving individual organizational ethics standards of ethical behavior.
\end{abstract}

\section{INTRODUCTION}

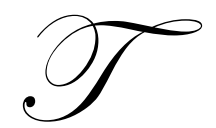

he previous decade has seen an eroding of accounting regulations by Congress under the direction of special interest groups and lobbyists. Now, under Sarbanes-Oxley Act of 2002 (SOX), if the company is indicted, the CEO and the board must prove they are directly overseeing and monitoring a comprehensive ethics program, or they will incur stiffer fines (Pohlman and Mujtaba, 2007). Under these conditions, the whole company must have a program that is compliant with SOX, which would ensure that ethical guidance comes from top management and continually is reinforced.

SOX requirements have changed the current business environment. In the past business ethics was viewed as important. Now, business ethics is mandatory, but where is the map for business managers to follow? SOX mandates ongoing comprehensive ethics programs, but does not give clear exact criteria, leaving the responsibility of education and training employees in ethics up to the organization. Business managers will be relying more on research for direction on how to make the most impact on training programs to positively influence ethical behavior.

To be ethical is to conform to moral standards or to conform to the standards of conduct of a given profession or group (Mujtaba, 2007; “Webster's New," 1977). According to Verschoor, 2004, expanded governance of SOX ignores the premise that the scandals were not due to inadequate laws and regulations. Verschoor believes they were due to a failure of ethical behavior.

SOX attempts to govern ethical behavior by hard-and-fast rules, but these attempts are contrary to Cascio and Aquinis's belief, which asserts ethical behavior adapts and changes in response to social norms and in response to the needs and interests of those served by a profession (Cascio and Aguinis, 2005). Can the ethical behavior of an employee who adapts to social norms or culture conform to a new set of rules? Can ethical behavior be dictated in response to a new set of rules?

Added to this process of making a decision is the conflict between one's personal moral philosophy and values and the culture of the organization. Organizational culture is the pervasive system of values, beliefs, and norms 
that exist in any corporation and can encourage or discourage moral decision-making (Gibson, Ivancevich, Donnelly, \& Konopaske, 2003).

The lesson from the high-profile corporate scandals is that the leaders of the organization set the example for the entire company, so that the remedy needed is not a new procedure, but corporate leaders who can be trusted and who have a record of building a culture for doing the right thing (Verschoor, 2004).

Moral development as an interdisciplinary field researches moral common sense and personal knowledge. It studies how children evolve a sense of right and wrong, good and bad, and how adults improve their abilities to handle ethical issues in day to day situations. Included here would be resolving value conflicts, increasing trust, managing cooperative and tolerant relationships, and setting ethical goals. The focus is on how one uses cognitive thinking skills when confronted with ethical issues and the subsequent actions that follow (Puka, 1994).

Kohlberg's studies are an example of decision-makers' personal values being developed by taking direction from the business environment; Kohlberg posits ethics and values are developed from one's interaction with the environment (Mujtaba, 1997; Kohlberg, 1973). Further, individuals form their values dynamically because they interact in an environment that constantly changes. Finance and accounting professionals need to understand that they bring their personal value system to a company that may have a conflicting corporate value system, as reported to exist at Enron.

In business ethics, managers use a different reasoning process depending on whether the problem is related to business, a broader societal issue, or personal issues (Elm \& Weber, 1994). Hence the need for ethical training, which research has shown can influence adults in ethical decision making and the reasoning process (Mujtaba, 1996).

James Rest claims the development of moral judgment is an important part of the psychology of morality as originally stated by Kohlberg (Rest et al., 1999). Further, Rest developed the four-component model as a synthesis of other approaches and different facets of morality. The four-component model suggests various inner psychological processes, which together give rise to outwardly observable behavior (Rest et al., 1999). These four processes are as follows:

1. Moral sensitivity - interpreting the situation and how various actions would affect all parties concerned, imagining cause-and-effect chains of events, and being aware that there is a moral problem when it exits (Rest et al., 1999).

2. Moral judgment - judging which action would be most justifiable in a moral sense by use of the Defining Issues Test (DIT). The DIT has been used to collect data for the last 25 years with validity and reliability (Rest et al., 1999).

3. Moral motivation - the degree of commitment in pursuing the moral course of action, placing higher value on moral judgment over other values, and taking personal responsibility for moral outcomes (Rest et al., 1999).

4. Moral character - persisting in a moral task, having courage, overcoming fatigue and temptations, and implementing behavior that serves a moral goal (Rest et al., 1999).

Rest proposes moral failure can occur because of a deficiency in any of the four components. The components are the processes that Rest developed as an analysis of what is necessary for a person to behave morally (Rest \& Narvaez, 1994). Rest states that the concept of moral judgment structure is actively constructed by the individual. The four component model as a theory explains moral behavior determinants and provides the different reasons a person might fail to behave morally (Rest \& Narvaez, 1994). Rest's model, which contains core ideas from Kohlberg's theory, appears to compensate for perceived shortcomings of Kohlberg's model, and uses the DIT.

In a study by Bassiry (1990) the course offerings on ethics and social issues at the graduate level were low in American business curricula. The author finds that many business schools train students for entry-level positions and no further. This explained the narrow focus of only technical coursework and the lack of broader ethical subject matter. Bassiry agrees that increasing awareness of the moral dimension serves as a vehicle for an individual to reflect 
on their own ethical values. It is this total educational experience that succeeds in implanting the necessary moral constructs to counter-balance the self- serving behavior in corporate decision-making. Figure 1 depicts a model that is consistent with the research.

Figure 1. Business Ethics Training Model

\begin{tabular}{|c|c|c|c|}
\hline $\begin{array}{l}\text { Organization } \\
\text { Culture }\end{array}$ & Philosophical Perspective & Diverse Reading & $\begin{array}{l}\text { Acceptance of the company's } \\
\text { code of conduct }\end{array}$ \\
\hline $\begin{array}{c}\text { Peers } \\
\text { Management }\end{array}$ & $\begin{array}{l}\text { Take the DIT } \\
\text { to have a bench mark for a } \\
\text { moral development score }\end{array}$ & Variety of Case Studies & $\begin{array}{l}\text { Leads to awareness of issues } \\
\text { and self awareness }\end{array}$ \\
\hline $\begin{array}{c}\text { Own Motives Values Beliefs } \\
\text { Socialization }\end{array}$ & $\begin{array}{l}\text { Take Myers Briggs for a } \\
\text { personality awareness }\end{array}$ & $\begin{array}{c}\text { Examine and Write Codes of } \\
\text { Conduct }\end{array}$ & $\begin{array}{l}\text { Leads to ability to question } \\
\text { motives- know right course } \\
\text { of action }\end{array}$ \\
\hline $\begin{array}{l}\text { Personal } \\
\text { Thoughts } \\
\text { Feelings }\end{array}$ & $\begin{array}{l}\text { Personal motives values, } \\
\text { beliefs }\end{array}$ & Integration / Reflection & $\begin{array}{c}\text { Addresses } \\
\text { Moral sensitivity, judgment, } \\
\text { and motivation to build moral } \\
\text { character }\end{array}$ \\
\hline
\end{tabular}

A results oriented business ethics training program will need to consider the organizational culture, including relationships of peers and management. In addition, the employee has to consider the motives, values, beliefs, and their socialization which creates their thoughts and feelings impacting ethical decisions. It is one's thoughts and feelings that need to align.

Next the program has to include a philosophical perspective, a tool like the Defining Issues Test (DIT) to benchmark a moral development score, and a personality assessment from a Myers Briggs type survey. The method of using benchmarks and assessment tools identifies areas that need improvement, allows for a test and re-test approach and enrollment in a continuous ethics training program.

The ethical training program needs this background information to proceed with diverse readings, a variety of case studies, examination and writing of codes of conduct and most important allowing time for the person to reflect and integrate the material.

Accordingly, this leads to awareness of moral issues, and self awareness which leads to improved ability to question motives and to identify right courses of action. Penalties for fraud would be included; however, that is not the main emphasis of this program. Lastly, to build moral character the inner process of moral sensitivity, judgment and motivation have to be developed which is the core emphasis of this model. Next the employee would apply this theory in their workplace; as demonstrated in Figure 2.

Figure 2. Application of Ethics Training

\begin{tabular}{|c|c|c|}
\hline Employee Analyses & $\begin{array}{l}\text { What Value are you creating/performing } \\
\text { for your company taking to work }\end{array}$ & Decisions/Choices \\
\hline Management Practices Analyses & $\begin{array}{l}\text { Take your personal and professional } \\
\text { moral awareness to work }\end{array}$ & Trust/Goals \\
\hline Culture Analyses & $\begin{array}{c}\text { Dominant leadership style, definitions } \\
\text { of success that characterize the } \\
\text { organization }\end{array}$ & Positive productive behavior \\
\hline $\begin{array}{l}\text { Organization/ } \\
\text { Business Analyses }\end{array}$ & Work experiences & How groups work together \\
\hline Government Laws & Incorporating Accepted Practices & $\begin{array}{l}\text { Keeping the spirit and the letter of the } \\
\text { law to avoid penalties }\end{array}$ \\
\hline
\end{tabular}


The purpose of a business ethics-training program will assist in ability to analyze the leadership, culture and core business of the employee. It will emphasize the value the employee is creating for the company and reminds people not to leave their heart at home. This inclusive approach will improve ethical choices and decision-making to deter compromise and penalties.

Training or education should develop fair-minded honest individuals with integrity, self-knowledge, and a deep concern for the welfare of others (Paul \& Elder, 2005). These are the values necessary to produce ethical behavior. Likewise, Kohlberg's research places these values in the highest level of moral maturity. To be ethical today takes courage and self-discipline to do what is right. Some individuals at Enron subordinated honesty to personal gain, confirming the failure in ethical behavior in the workplace (Duska, 2005).

\section{SUMMARY}

In order to maintain excellence in ethical behavior, values have to be reinforced routinely to have congruency with ethical behavior (Thorp, 2005). Hence, there is a need for ethical education and training to counter one's underdeveloped personal values and the lack of proper business values.

John Adams wrote, "The preservation of liberty depends upon the intellectual and moral character of the people" (Smith, 2003, 49). Benjamin Franklin wrote, "Only a virtuous people are capable of freedom" (Smith, 2003, 49). According to Pohlman and Mujtaba (2007), Sarbanes-Oxley has forced the hand of corporations to uphold ethical behavior. Training and educational programs are needed to instill the kind of behaviors that support business environments where integrity is the norm across the organization.

\section{REFERENCES}

1. Rest. J., \& Narvaez, D. (1994). Moral development in the professions. Hillsdale, NJ: Lawrence Erlbaum Associates, Inc.

2. Bassiry, G. (1990, October). Ethics, education, and corporate leadership. Journal of Business Ethics, 9(10), 799-805.

3. Cascio, W. and Aguinis, H. (2005). Applied psychology in human resource management (6th ed.). Upper Saddle River, NJ: Prentice Hall.

4. Cavico, F., \& Mujtaba, B. G. (2005). Business Ethics: Transcending Requirements through Moral Leadership. Boston, MA: Pearson Custom Publishing.

5. Duska, R. (2005, September). A look at integrity in financial services. Journal of Financial Service Professionals, 59(5), 26.

6. Gibson, J., Ivancevich, J., Donnelly, J., \& Konopaske, R. (2003). Organizations behavior structure process (11th ed.). New York: McGraw Hill Companies.

7. Kohlberg, L. (1973). The contribution of development psychology to education examples from moral education. Education Psychology, 10(1).

8. Mujtaba, B. G. (2007). The ethics of management and leadership in Afghanistan (2 ${ }^{\text {nd }}$ edition). ILEAD Academy. ISBN: 978-0-9774211-0-7. Davie, Florida USA.

9. Mujtaba, B. G. (1997). Business Ethics Survey of Supermarket Managers and Employees. UMI Dissertation Service. A Bell \& Howell Company. UMI Number: 9717687. Phone: (313) 761-4700. (800) 521-0600.

10. Mujtaba, B. G. (1996). Ethics and morality in business. Journal of Global Competitiveness, 4(1).

11. Paul, R., \& Elder, L. (2005). Foundation for critical thinking, the miniature guide to understanding the foundations of ethical reasoning. Retrieved June 20, 2005, from http://www.criticalthinking.org/TGS_files/SAMEthicalReasoning2005.pdf

12. Puka, B. (Ed.). (1994). The great justice debate: Kohlberg criticism. Moral development: A compendium, Vol. 4. New York: Garland Publishing, Inc.

13. Rest. J., Narvaez, D., Bebeau, M., \& Thoma, S. (1999). Postconventional Moral Thinking. Mahwah, NJ: Lawrence Erlbaum Associates, Inc.

14. Sarbanes-Oxley Act of 2002, H.R. 3763, 107th Cong. (2002). Retrieved April 25, 2004, from http://news.findlaw.com/hdocs/docs/gwbush/sarbanesoxley072302.pdf

15. Smith, L. (2003). A fresh look at accounting ethics. Accounting Horizons, 17(1), 47,29.

16. Thorp, J. (2005). Values and ethics for CPAs in a changing world. The CPA Journal, 75(8), 18.

17. Verschoor, C. (2004, January). Toward a corporation with conscience. Strategic Finance, 4(85), 20.

18. Webster's new collegiate dictionary. (1977). Springfield, MA: Merriam-Webster 